\title{
Impact of scavenging hydrogen peroxide in the endoplasmic reticulum for $\beta$ cell function
}

\author{
S Lortz, S Lenzen and I Mehmeti
}

Hannover Medical School, Institute of Clinical Biochemistry, 30623 Hannover, Germany

Correspondence should be addressed to S Lortz

Email

Lortz.Stephan@

mh-hannover.de

\begin{abstract}
Oxidative folding of nascent proteins in the endoplasmic reticulum (ER), catalysed by one or more members of the protein disulfide isomerase family and the sulfhydryl oxidase ER oxidoreductin 1 (ERO1), is accompanied by generation of hydrogen peroxide $\left(\mathrm{H}_{2} \mathrm{O}_{2}\right)$. Because of the high rate of insulin biosynthesis and the low expression of $\mathrm{H}_{2} \mathrm{O}_{2}$-inactivating enzymes in pancreatic $\beta$ cells, it has been proposed that the luminal $\mathrm{H}_{2} \mathrm{O}_{2}$ concentration might be very high. As the role of this $\mathrm{H}_{2} \mathrm{O}_{2}$ in ER stress and proinsulin processing is still unsolved, an ER-targeted and luminal-active catalase variant, ER-Catalase N244, was expressed in insulin-secreting INS-1E cells. In these cells, the influence of ER-specific $\mathrm{H}_{2} \mathrm{O}_{2}$ removal on cytokine-mediated cytotoxicity and ER stress, insulin gene expression, insulin content and secretion was analysed. The expression of ER-Catalase N244 reduced the toxicity of exogenously added $\mathrm{H}_{2} \mathrm{O}_{2}$ significantly with a threefold increase of the $\mathrm{EC}_{50}$ value for $\mathrm{H}_{2} \mathrm{O}_{2}$. However, the expression of cytokine-induced ER stress genes and viability after incubation with $\beta$ cell toxic cytokines (IL1 $\beta$ alone or together with TNF $\alpha+$ IFN $\gamma$ ) was not affected by ER-Catalase N244. In control and ER-Catalase N244 expressing cells, insulin secretion and proinsulin content was identical, while removal of luminal $\mathrm{H}_{2} \mathrm{O}_{2}$ reduced insulin gene expression and insulin content in ER-Catalase N244 expressing cells. These data show that ER-Catalase $\mathrm{N} 244$ reduced $\mathrm{H}_{2} \mathrm{O}_{2}$ toxicity but did not provide protection against pro-inflammatory cytokine-mediated toxicity and ER stress. Insulin secretion was not affected by decreasing $\mathrm{H}_{2} \mathrm{O}_{2}$ in the ER in spite of a reduced insulin transcription and processing.
\end{abstract}

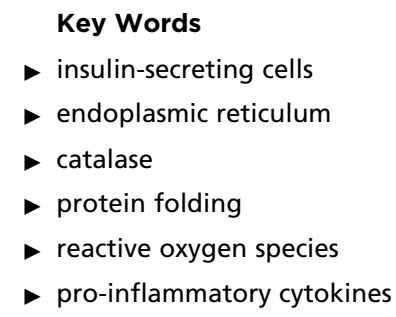

Journal of Molecular Endocrinology (2015) 55, 21-29

\section{Introduction}

Biosynthesis and secretion of insulin in response to glucose are the major tasks of pancreatic $\beta$ cells. Endoplasmic reticulum (ER) is highly developed in these professional secretory cells to ensure oxidative protein folding and posttranslational modification of the synthesised proteins (Harding \& Ron 2002). Since insulin, the main product of protein synthesis in the $\beta$ cells, is not glycosylated, the most important function of the ER is the formation of three disulfide bonds in each insulin molecule (Bulleid 2012). During this oxidative folding process the formation of each disulfide bond, thought to be catalysed by one or more members of the protein disulfide isomerase (PDI) family, and the sulfhydryl oxidase ER oxidoreductin 1 (ERO1), is associated with the generation of one molecule hydrogen peroxide $\left(\mathrm{H}_{2} \mathrm{O}_{2}\right)$ as a by-product (Tu \& Weissman 2004, Ramming \&

Published by Bioscientifica Ltd. 
Appenzeller-Herzog 2012). Through the large number of proinsulin molecules to be synthesised and processed in each $\beta$ cell, an estimated one million molecules per minute (Scheuner \& Kaufman 2008), the ER, along with the mitochondria and peroxisomes, represents a major site of $\mathrm{H}_{2} \mathrm{O}_{2}$ generation ( $\mathrm{Tu} \&$ Weissman 2004). However, the fate of the ER-generated $\mathrm{H}_{2} \mathrm{O}_{2}$ and its importance for the maintenance of ER homeostasis and oxidative folding efficacy is still unresolved. A number of studies indicate that this luminal $\mathrm{H}_{2} \mathrm{O}_{2}$ generation is mandatory for retaining and improving the oxidative protein folding capacity of the ER (Margittai et al. 2012, Ramming \& Appenzeller-Herzog 2013). This $\mathrm{H}_{2} \mathrm{O}_{2}$ is required for the re-oxidation of the reduced PDI protein by ER-localised glutathione peroxidases (GPx7 and GPx8) and potentially also by peroxiredoxin $4(\operatorname{Prdx} 4)$. On the other hand, the activation of the ER stress pathway, which may lead to apoptotic cell death, has also been associated to the fulminant ROS generation in the ER (Malhotra et al. 2008, Bhandary et al. 2012, Cao \& Kaufman 2014).

To shed light on this contentious issue, we took advantage of a recently developed catalase variant, ER-Catalase N244, which shows full enzyme activity upon expression in the ER (Lortz et al. 2015). In insulinsecreting INS-1E tissue culture cells, we studied the influence of a high luminal $\mathrm{H}_{2} \mathrm{O}_{2}$ inactivating activity on insulin expression and secretion. Furthermore, the role of ER-derived $\mathrm{H}_{2} \mathrm{O}_{2}$ in the initiation of ER stress cascades and the reduction of cell viability through $\beta$ cell toxic cytokines has been investigated.

\section{Materials and methods}

\section{Tissue culture of insulin-producing cells}

Insulin-secreting INS-1E tissue culture cells (kindly provided by C. Wollheim, University of Geneva Medical Center, Geneva, Switzerland) were cultured in RPMI 1640 medium supplemented with $10 \mathrm{mmol} / \mathrm{l}$ glucose, $10 \%(\mathrm{v} / \mathrm{v})$ FCS, $10 \mathrm{mmol} / 1$ HEPES, $1 \mathrm{mmol} / 1$ sodium pyruvate, $50 \mu \mathrm{mol} / 1$ 2-mercaptoethanol, penicillin, and streptomycin in a humidified atmosphere at $37{ }^{\circ} \mathrm{C}$ and $5 \% \mathrm{CO}_{2}$ as described previously (Asfari et al. 1992).

\section{Lentiviral expression of ER-localised catalase in INS-1E cells}

To express catalase specifically in the ER, the mutated catalase variant ER-Catalase N244 cDNA was used (Lortz et al. 2015). For this purpose, lentiviral particles were prepared as described before in detail (Zufferey et al. 1998). $4 \times 10^{6} 293 \mathrm{~T}$ cells were transfected with the packaging plasmid pPAX2 $(11.25 \mu \mathrm{g})$, the envelope plasmid pcDNAMDG $(3.75 \mu \mathrm{g})$, and the transfer plasmid pLenti6.3/ V5-MCS-ER-Catalase N244 (15 $\mu \mathrm{g})$ by calcium phosphate precipitation. After $48 \mathrm{~h}$ the virus containing culture medium was collected and centrifuged for $5 \mathrm{~min}$ at $700 \boldsymbol{g}$ to remove detached cells and cell debris; then the supernatant was filtered through $0.22 \mu \mathrm{m}$ filters (Merck Millipore, Darmstadt, Germany). The INS-1E cells were infected with the purified viral supernatant for 5-6 h and thereafter the viral supernatant was replaced by fresh medium. Transduced cells were selected for catalase expression by $1 \mu \mathrm{M}$ blasticidin (Life Technologies). These selected cells represented a mixed cell population. Thus, integration of the lentiviral construct happens randomly at various genomic locations and possible undesirable interactions with specific genes, altering $\beta$ cell function, are less likely. Therefore the use of these cells, in contrast to single cell clones, can avoid unwanted clonal selection artefacts.

\section{Quantification of catalase activity}

Catalase activity was quantified as described (Tiedge et al. 1998). Briefly, whole cell extracts were prepared in $50 \mathrm{mmol} / \mathrm{l}$ potassium phosphate buffer $(\mathrm{pH}$ 7.8) through sonication on ice with a Braun-Sonic 125 sonifier (Braun, Melsungen, Germany). The homogenates were then centrifuged at $10000 \mathrm{~g}$ and $4{ }^{\circ} \mathrm{C}$ for $10 \mathrm{~min}$ and the protein content of the supernatant was determined by the BCA assay (Thermo Fisher Scientific, Rockford, IL, USA). The catalase activity was measured by ultraviolet spectroscopy, monitoring the decomposition of $\mathrm{H}_{2} \mathrm{O}_{2}$ at $240 \mathrm{~nm}$.

\section{Immunofluorescence staining}

INS-1E cells expressing ER-Catalase N244 or WT catalase without an ER-specific targeting signal were seeded at a density of 100000 cells/well on LabTek chamber slides (Nunc, Roskilde, Denmark). After $48 \mathrm{~h}$, the cells were washed twice with PBS and subsequently fixed with $4 \%$ paraformaldehyde at room temperature for $1 \mathrm{~h}$. After washing, the cells were permeabilised and blocked with PBS containing $0.2 \%$ Triton X-100 and 1\% BSA. The cells were incubated with primary antibodies (anti-PDI, ab5484, Abcam, Cambridge, UK, 1:100 dilution; anticatalase, 100-4151, Rockland Immunochemicals, Inc., Limerick, PA, USA, 1:500 dilution) diluted in PBS containing $0.1 \%$ Triton $\mathrm{X}-100$ and $0.1 \%$ BSA at room temperature for $1 \mathrm{~h}$. Thereafter the cells were washed with

Published by Bioscientifica Ltd. 
PBS and incubated with specific secondary antibodies (anti-mouse-Alexa Fluor 647, or anti-rabbit-Alexa Fluor 488, Jackson ImmunoResearch Laboratories, West Grove, PA, USA; 1:200 dilutions) for $1 \mathrm{~h}$ in the dark. Afterwards the cells were washed and the nuclei were counterstained with $300 \mathrm{nM}$ DAPI for $5 \mathrm{~min}$ at room temperature. Finally, the cells were washed and mounted with Mowiol/DABCO anti-photobleaching mounting media (Sigma). Stained cells were examined with an Olympus IX81 inverted microscope (Olympus) and microscopic images were post-processed using AutoDeblur and AutoVisualize (Autoquant Imaging, New York, NY, USA).

\section{Quantification of cell viability after $\mathrm{H}_{2} \mathrm{O}_{2}$ treatment}

After 24 h seeding of 40000 cells/well of a 96-well plate, cells were incubated with the indicated $\mathrm{H}_{2} \mathrm{O}_{2}$ concentrations (INS-1E: 0-125 $\mu \mathrm{M}$, INS-1E ER-Catalase: $0-1250 \mu \mathrm{M}$ ) for $2 \mathrm{~h}$ in $20 \mathrm{mmol} / \mathrm{l}$ HEPES-supplemented Krebs-Ringer bicarbonate medium with $5 \mathrm{mmol} / \mathrm{l}$ glucose. After removal of the $\mathrm{H}_{2} \mathrm{O}_{2}$ containing medium the cells were incubated for another $22 \mathrm{~h}$ in fresh RPMI 1640 medium and thereafter cell viability was determined by a microplate-based MTT assay (3-(4,5-dimethylthiazol-2-yl)-2,5-diphenyl tetrazolium bromide) (Sigma) (Mosmann 1983). Briefly, the incubation medium was carefully removed and replaced by MTT-solution $(0.5 \mathrm{mg} / \mathrm{ml})$. After $1 \mathrm{~h}$ incubation at $37^{\circ} \mathrm{C}$, the MTT solution was carefully removed and the intracellularly generated water-insoluble formazan crystals were dissolved in DMSO. The absorbance was quantified using a microplate photometer (Powerwave 340, BioTek Instruments, Winooski, VT, USA).

\section{Quantification of cell viability after exposure to pro-inflammatory cytokines}

Cells were seeded at a density of 25000 cells/well in $100 \mu \mathrm{l}$ culture medium onto 96-well plates and allowed to attach for $24 \mathrm{~h}$ before they were incubated for $72 \mathrm{~h}$ with $600 \mathrm{U} / \mathrm{ml}$ human IL1 $\beta$ or a combination of cytokines (cytokine mixture) consisting of $60 \mathrm{U} / \mathrm{ml}$ IL1 $\beta, 185 \mathrm{U} / \mathrm{ml}$ human TNF $\alpha$, and $14 \mathrm{U} / \mathrm{ml}$ IFN $\gamma$ (PromoCell, Heidelberg, Germany). Thereafter the cell viability was determined by using a microplate-based MTT assay.

\section{Quantification of ER stress after exposure to pro-inflammatory cytokines}

Cells were seeded on $6 \mathrm{~cm}$ tissue culture plates at a density of $1 \times 10^{6}$ cells and allowed to attach for a period of $24 \mathrm{~h}$.
Thereafter the cells were exposed for $16 \mathrm{~h}$ to $600 \mathrm{U} / \mathrm{ml}$ human IL1 $\beta$ or a combination of cytokines (cytokine mixture) consisting of $60 \mathrm{U} / \mathrm{ml}$ IL1 $\beta, 185 \mathrm{U} / \mathrm{ml}$ human $\mathrm{TNF} \alpha$, and $14 \mathrm{U} / \mathrm{ml} \mathrm{IFN} \gamma$. After cytokine incubation total RNA was isolated as previously described (Tiedge et al. 1998). For cDNA synthesis, random hexamers were used to prime the reaction of the RevertAid $\mathrm{H}-\mathrm{M}-\mathrm{MuLV}$ reverse transcriptase (Life Technologies). The reactions were performed with GoTaq qPCR Master Mix (Promega) in a ViiA 7 real-time PCR system (Life Technologies). Samples were denatured at $94{ }^{\circ} \mathrm{C}$ for $3 \mathrm{~min}$ followed by 40 PCR cycles. Each cycle comprised a melting step at $94^{\circ} \mathrm{C}$ for $30 \mathrm{~s}$, an annealing step at $60^{\circ} \mathrm{C}$ for $30 \mathrm{~s}$, and an extension step at $72{ }^{\circ} \mathrm{C}$ for $30 \mathrm{~s}$. Optimal parameters for the PCR reactions were empirically defined and the purity and specificity of the amplified PCR product in each experiment was verified by melting curve analysis. All transcripts showed $C_{t}$-values, which were at least ten $C_{t}$-values lower than the blank values. Each PCR amplification was performed in triplicate. Data are expressed as relative gene expression after normalisation against the geometric mean of the housekeeping genes Tuba4a, Actb and Ppia with qbasePLUS (Biogazelle, Zulte, Belgium). The primer sequences are listed in Table 1.

\section{Quantification of glucose-induced insulin secretion, insulin and proinsulin content}

INS-1E cells were seeded in six-well plates at a density of $0.5 \times 10^{6}$ cells and grown for $48 \mathrm{~h}$. Then the cells were incubated for $1 \mathrm{~h}$ in bicarbonate-buffered Krebs-Ringer solution without glucose, supplemented with $0.1 \%$ albumin. Thereafter the cells were stimulated for $2 \mathrm{~h}$ either with 3, 10, or $30 \mathrm{mmol} / \mathrm{l}$ glucose. After incubation, medium was removed and gently centrifuged to remove detached cells. Secreted insulin in the supernatant and insulin content of the incubated cells were determined by RIA using rat insulin as standard and the resulting values were normalised to DNA content. Proinsulin content was quantified by a rat proinsulin specific ELISA according to the manufacturer's protocol (Mercodia, Uppsala, Sweden).

\section{Statistical analyses}

Data are expressed as means \pm s.E.M. Statistical analyses were performed using ANOVA plus Bonferroni test for multiple comparisons or unpaired two-tailed Student's $t$-test. The $\mathrm{EC}_{50}$ values for the $\mathrm{H}_{2} \mathrm{O}_{2}$-induced toxicity were calculated from the concentration-response curves fitted by the sigmoidal concentration-response logarithm.

Published by Bioscientifica Ltd. 
Table 1 List of primers for the detection of ER stress-related genes by RT-qPCR

\begin{tabular}{|c|c|c|}
\hline Gene & Gene symbol & Oligonucleotide sequence $\left(5^{\prime}-3^{\prime}\right)$ \\
\hline ER stress specific genes & & \\
\hline Activating transcription factor 4 & Atf4 & $\begin{array}{l}\text { Forward: 5'-AATGGCTGGCTATGGATGGG-3' } \\
\text { Reverse: } 5^{\prime} \text {-TCTGTCCCGGAAAAGGCATC-3' }\end{array}$ \\
\hline Activating transcription factor 6 & Atf6 & $\begin{array}{l}\text { Forward: 5'-GAGAGGTGTCTGTTTCGGGG-3' } \\
\text { Reverse: } 5^{\prime} \text {-CGTGGACTCCCAGTCTTCAC-3' }\end{array}$ \\
\hline C/EBP homologous protein & Chop & $\begin{array}{l}\text { Forward: 5'-CCAGCAGAGGTCACAAGCAC-3' } \\
\text { Reverse: } 5^{\prime} \text {-CGCACTGACCACTCTGTTTC-3' }\end{array}$ \\
\hline Glucose-regulated protein, 78 kDa & Grp78/Bip & $\begin{array}{l}\text { Forward: 5'-CCACCAGGATGCAGACATTG-3' } \\
\text { Reverse: } 5^{\prime} \text {-AGGGCCTCCACTTCCATAGA-3' }\end{array}$ \\
\hline $\begin{array}{l}\text { Housekeeping genes } \\
\alpha \text {-tubulin } 4 a\end{array}$ & Tuba4a & $\begin{array}{l}\text { Forward: 5'-ACGTGAGACGTACATCCCAAACTCA-3' } \\
\text { Reverse: } 5^{\prime} \text {-CTCCCAGCAGGCATTGCCCA-3' }\end{array}$ \\
\hline$\beta$-actin & Actb & $\begin{array}{l}\text { Forward: 5'-GCGTCCACCCGCGAGTACAA-3' } \\
\text { Reverse: } 5^{\prime} \text {-TTGCAATGCCGGAGCCGTT-3' }\end{array}$ \\
\hline Peptidylprolyl isomerase A (cyclophilin A) & Ppia & $\begin{array}{l}\text { Forward: 5'-TTGCAGACGCCGCTGTCTCTT-3' } \\
\text { Reverse: 5'-TGGAACTTTGTCTGCAAACAGCTCG-3' }\end{array}$ \\
\hline
\end{tabular}

All analyses were performed with the GraphPad Prism 5.03 Software (Graphpad, San Diego, CA, USA).

\section{Results}

Subcellular localisation of ER-Catalase N244 and quantification of ER-Catalase N244 enzyme activity and its effect on $\mathrm{H}_{2} \mathrm{O}_{2}$ induced toxicity in INS-1E cells

To document the functional expression of ER-Catalase N244 in insulin-secreting INS-1E cells, the enzyme activity of cell lysates was quantified after lentiviral transduction. ER-Catalase-N244 expressing INS-1E cells showed with $148.5 \pm 4.9 \mathrm{U} / \mathrm{mg}$ protein a significantly higher enzyme activity than untransfected control cells $(10.3 \pm 3.2 \mathrm{U} / \mathrm{mg}$ protein, $P<0.001$ ) (data not shown). As the ER-specific expression is crucial, an immunofluorescence staining was performed. The co-staining of catalase and PDI in Fig. 1 documents a colocalisation in the ER confirming the ER-specific expression of ER-Catalase N244 in the INS-1E cells. In contrast, INS-1E cells overexpressing the unmodified WT catalase showed no clear colocalisation
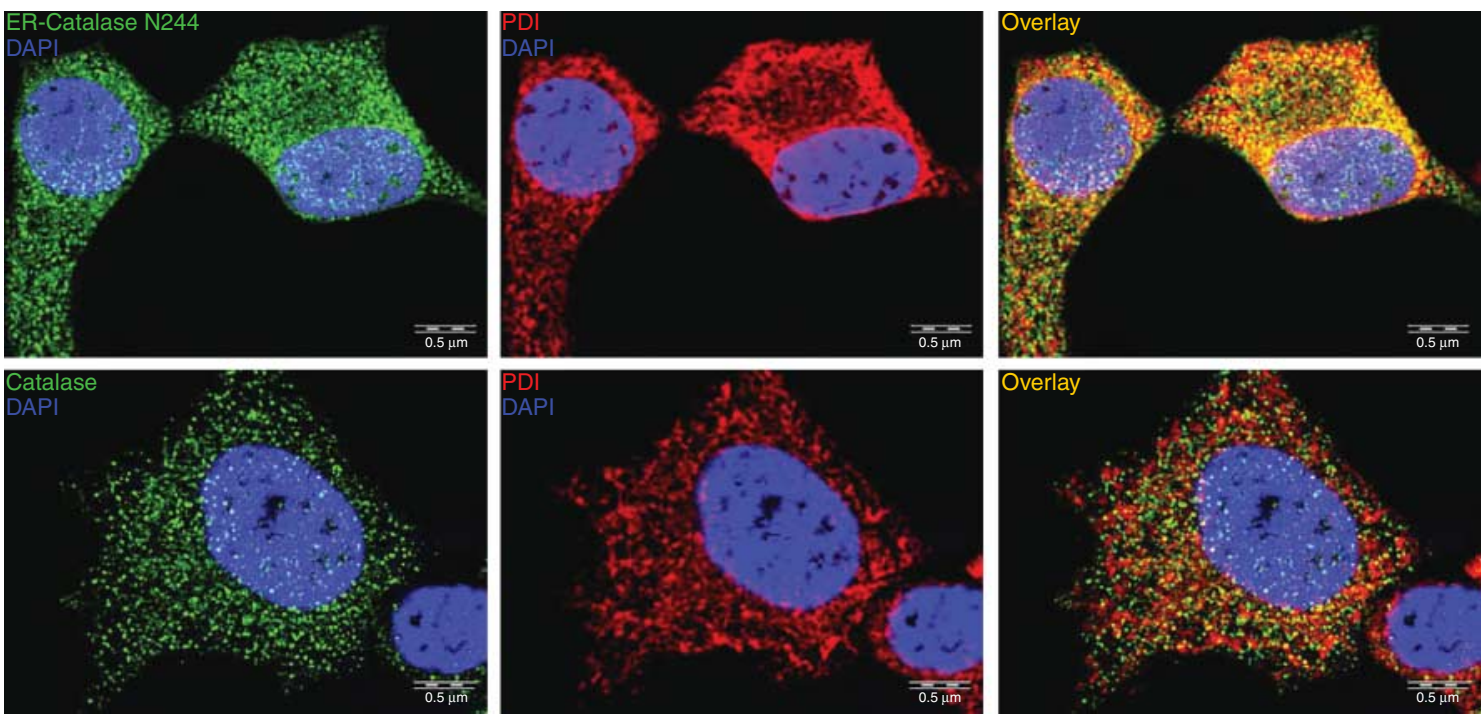

\section{Figure 1}

Subcellular localisation of ER-Catalase N244 and WT catalase in insulinsecreting INS-1E cells. Cells were seeded on LabTek chamber slides. After fixation and permeabilisation the cells were stained with specific antibodies

$\begin{array}{lr}\text { http://jme.endocrinology-journals.org } & \text { C } 2015 \text { Society for Endocrinology } \\ \text { DOI: } 10.1530 / \mathrm{ME}-15-0132 & \text { Printed in Great Britain }\end{array}$

for catalase (green) and for the ER-specific protein disulfide isomerase (PDI, red), followed by counterstaining with DAPI (blue). A full colour version of this figure is available at http://dx.doi.org/10.1530/JME-15-0132. 


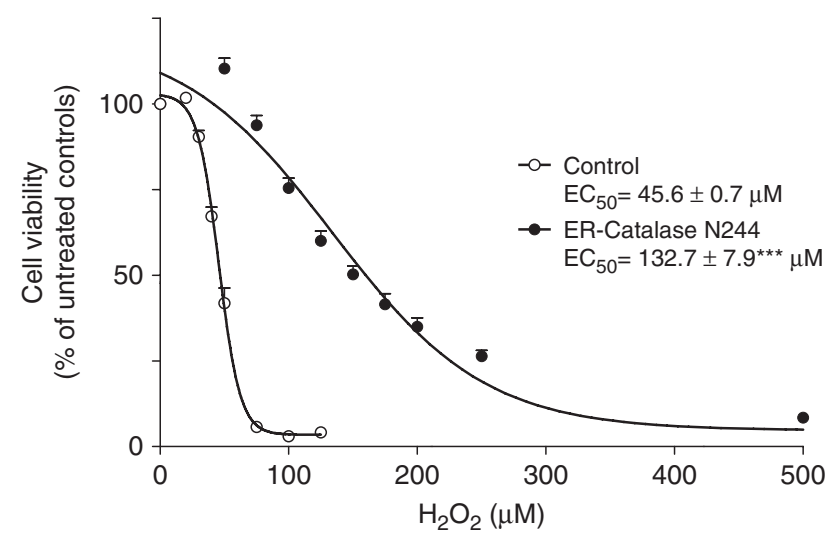

Figure 2

Effects of ER-Catalase N244 expression on cytotoxicity after incubation of INS- $1 \mathrm{E}$ cells with $\mathrm{H}_{2} \mathrm{O}_{2}$. INS-1E control and ER-Catalase $\mathrm{N} 244$ expressing cells were incubated for $2 \mathrm{~h}$ with the indicated $\mathrm{H}_{2} \mathrm{O}_{2}$ concentrations in Krebs-Ringer medium, and after removal of the $\mathrm{H}_{2} \mathrm{O}_{2}$-containing medium for another $22 \mathrm{~h}$ in fresh medium. Thereafter, the viability of the cells was determined by the MTT assay and expressed as \% of untreated cells. Data are expressed as mean \pm s.E.M. of six to eight independent experiments. ${ }^{* *} P<0.001$ compared with control cells (unpaired two-tailed Student's $t$-test).

of catalase and PDI (Fig. 1, lower panel). Thus, only the ER-targeted catalase variant ER-Catalase N244 was expressed in the ER, while the native catalase protein was localised outside the ER, presumably in the cytosol and the peroxisomes. To demonstrate the in vivo functionality of the expressed ER-Catalase N244 and to provide an estimate of its $\mathrm{H}_{2} \mathrm{O}_{2}$ inactivating capacity, INS-1E control and ER-Catalase N244 expressing cells were incubated with increasing $\mathrm{H}_{2} \mathrm{O}_{2}$ concentrations and the cell viability was determined thereafter. Both cell clones showed a concentration-dependent decrease of their cell viability with an $\mathrm{EC}_{50}$ value of $45.6 \mu \mathrm{M} \mathrm{H}_{2} \mathrm{O}_{2}$ for the control cells (Fig. 2) and a significantly higher $\mathrm{EC}_{50}$ value of $132 \mu \mathrm{M}$ for
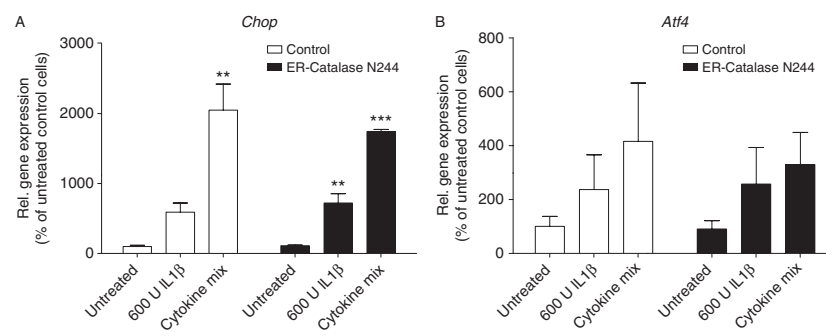

Figure 3

Effects of ER-Catalase N244 expression on the induction of ER stress genes after incubation of INS-1E cells with cytokines. INS-1E control and ER-Catalase N244 expressing cells were incubated for $16 \mathrm{~h}$ under control conditions, with $600 \mathrm{U} / \mathrm{ml} \mathrm{IL1 \beta}$ or with a cytokine mixture, composed of $60 \mathrm{U} / \mathrm{ml} \mathrm{IL} 1 \beta, 185 \mathrm{U} / \mathrm{ml} \mathrm{TNF} \alpha$, and $14 \mathrm{U} / \mathrm{ml} \mathrm{IFN} \gamma$. After incubation, total RNA was isolated and the expression of Chop (A), Atf4 (B), Atf6 (C), and the ER-Catalase N244 expressing cells $(P<0.001$, Fig. 2$)$. These differences in the $\mathrm{EC}_{50}$ values were especially obvious at concentrations up to $100 \mu \mathrm{M}$, which is the most relevant range for physiological and pathological processes. At $50 \mu \mathrm{M} \mathrm{H}_{2} \mathrm{O}_{2}$, the ER-Catalase expressing cells showed no decrease in cell viability and at $100 \mu \mathrm{M}$ a residual cell viability of still $75 \%$ could be detected, whereas the control cells showed at the same $\mathrm{H}_{2} \mathrm{O}_{2}$ concentrations only a residual viability of 42 and $2 \%$, respectively (Fig. 2).

\section{Effects of ER-Catalase N244 on the ER stress response after exposure of INS-1E cells to pro-inflammatory cytokines}

To determine the influence of ER-specific detoxification of $\mathrm{H}_{2} \mathrm{O}_{2}$ on the initiation of ER stress in response to $\beta$ cell toxic cytokines, the gene expression of three major mediators of ER stress, namely Chop, Atf4, and Atf6, and of the ER-chaperon Grp78/Bip was quantified by RT-qPCR. As shown in Fig. 3A, a $16 \mathrm{~h}$ exposure to $600 \mathrm{U} / \mathrm{ml}$ IL1 $\beta$ alone resulted in a sixfold and incubation with a cytokine mixture $(60 \mathrm{U} / \mathrm{ml}$ IL1 $\beta, 185 \mathrm{U} / \mathrm{ml} \mathrm{TNF} \alpha$, and $14 \mathrm{U} / \mathrm{ml}$ IFN $\gamma$ ) in a 20-fold increase of Chop gene expression in INS-1E control cells. Both, Atf4 and Atf6, were induced by the cytokine treatment, but to a much lower extent compared with Chop. However, Atf4 gene expression was induced by IL1 $\beta$ (2.4-fold) and the cytokine mixture (4.2-fold), as well as Atf6 (1.2- and 2.2-fold respectively) (Fig. 3B and C). At variance from the increased expression of the investigated ER stress mediators Chop, Atf4, and Atf6, the expression of the ER located chaperon Grp78/Bip was significantly reduced by IL $1 \beta$ alone and the cytokine mixture. After both incubations Bip expression was reduced approx. $40 \%$.
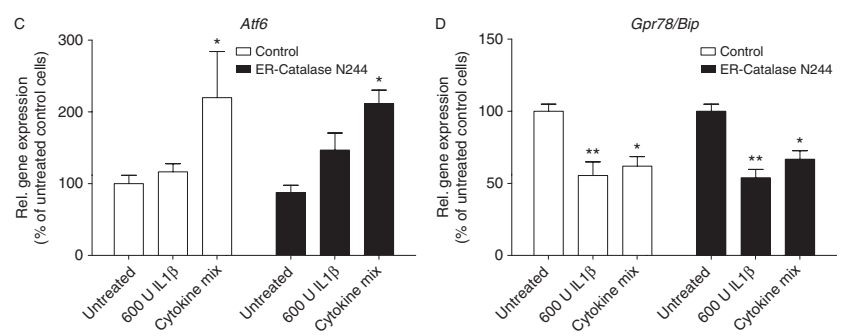

Grp78/Bip (D) was analysed by RT-qPCR with specific primers. The expression levels were normalised to the housekeeping genes Tuba4a, $A c t b$, and Ppia. The gene expression level of untreated control cells was set as $100 \%$. Data are expressed as means \pm s.E.M. of three independent experiments. ${ }^{*} P<0.05, * * P<0.01$ and $* * * P<0.001$ compared with untreated cells (ANOVA plus Bonferroni test for multiple comparisons).

Published by Bioscientifica Ltd. 
The expression level of all four investigated ER stress related genes in ER-Catalase N244 expressing INS-1E cells under control conditions and after cytokine exposure was comparable to that in control cells and no significant differences could be detected. These data indicate that expression of ER-Catalase N244 in INS-1E cells and thereby reduction of luminal $\mathrm{H}_{2} \mathrm{O}_{2}$ did not alter the expression of the ER stress-induced genes Chop, Atf4, and Atf6 and of the ER located chaperon Grp78/Bip after cytokine exposure.

\section{Effects of ER-Catalase N244 on cell viability after exposure of INS-1E cells to pro-inflammatory cytokines}

After having shown that ER-specific inactivation of $\mathrm{H}_{2} \mathrm{O}_{2}$ had no influence on the cytokine-induced expression of ER stress genes, we also analysed the effect of ER-Catalase N244 expression on cytokine-mediated cellular toxicity.

Therefore transfected and untransfected insulinsecreting INS-1E cells were incubated again with $600 \mathrm{U} / \mathrm{ml}$ IL1 $\beta$ or with the cytokine mixture $(60 \mathrm{U} / \mathrm{ml}$ IL1 $\beta, 185 \mathrm{U} / \mathrm{ml} \mathrm{TNF} \alpha$, and $14 \mathrm{U} / \mathrm{ml}$ IFN $\gamma$ ). After a $72 \mathrm{~h}$ incubation with IL1 $\beta$ a substantial $85 \%$ loss of viability could be detected for the INS-1E control cells $(P<0.001)$. With the cytokine mixture this loss of viability was only slightly augmented (Fig. 4). The viability of ER-Catalase N244 expressing INS-1E cells after cytokine treatment did not significantly differ from untransfected control cells.

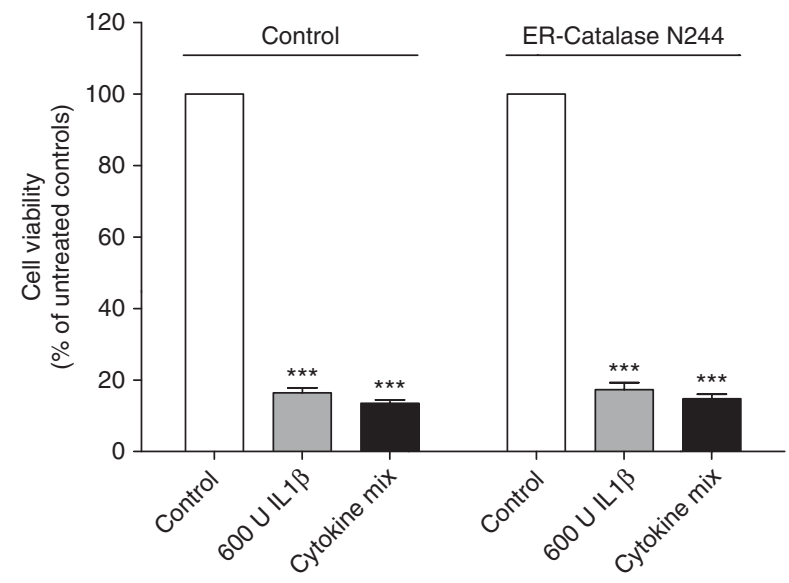

Figure 4

Effects of ER-Catalase N244 expression on cytotoxicity after incubation of INS-1E cells with cytokines. INS-1E control and ER-Catalase N244 expressing cells were incubated for $72 \mathrm{~h}$ under control conditions, with $600 \mathrm{U} / \mathrm{ml} \mathrm{IL1} \beta$ or with a cytokine mixture, consisting of $60 \mathrm{U} / \mathrm{ml} \mathrm{IL} 1 \beta, 185 \mathrm{U} / \mathrm{ml} \mathrm{TNF} \alpha$, and $14 \mathrm{U} / \mathrm{ml}$ IFN $\gamma$. The cell viability was determined thereafter by the MTT viability assay and expressed as $\%$ of untreated cells. Data are expressed as means \pm s.E.M. of five independent experiments. $* * * P<0.001$ compared with untreated cells (ANOVA plus Bonferroni test for multiple comparisons).

\section{Effects of ER-Catalase N244 on glucose-induced insulin secretion and insulin content of INS-1E cells}

To study the influence of ER-specific $\mathrm{H}_{2} \mathrm{O}_{2}$ deprivation on glucose-induced insulin secretion, INS-1E cells were incubated for $2 \mathrm{~h}$ either with 3,10 , or $30 \mathrm{mM}$ glucose and thereafter the amount of secreted insulin was quantified in the supernatant. Basal insulin secretion of INS-1E control cells at $3 \mathrm{mM}$ glucose was $0.6 \mathrm{ng} /(\mu \mathrm{g} / \mathrm{DNA}$ per $\mathrm{h}$ ) and was more than fourfold elevated by 10 and $30 \mathrm{mM}$ glucose to $\sim 2.8 \mathrm{ng} /(\mu \mathrm{g} / \mathrm{DNA}$ per $\mathrm{h})(10 \mathrm{mM}$, $P<0.001 ; 30 \mathrm{mM}, P<0.005$ ) (Fig. 5A). The insulin content of the INS-1E control cells was $28 \mathrm{ng} / \mu \mathrm{g}$ DNA and the proinsulin content was 5-6 ng/ $\mathrm{gg}$ DNA, both without significant differences between the different glucose concentrations (Fig. 5B and C). The rate of glucoseinduced insulin secretion from the ER-Catalase N244 expressing INS-1E cells was comparable to that of control INS-1E cells at all glucose concentrations, including the rate of basal insulin secretion at $3 \mathrm{mM}$ (Fig. 5A). Although the proinsulin content in the ER-Catalase N244 transfected INS-1E cells remained unchanged at all three glucose concentrations, the insulin content was significantly lower and represented only two-thirds of that of untransfected control cells (Fig. 5B and C). Thus, the ratio between insulin and proinsulin content in control INS-1E cells was almost twice as high as in ER-Catalase N244 expressing cells (Fig. 5D).

\section{Effects of ER-Catalase N244 on insulin gene expression in INS-1E cells}

To determine whether the observed decreased insulin content might be a result of a lower insulin biosynthesis, the mRNA expression level of the insulin 1 and insulin 2 genes was quantified. Although the insulin 1 gene expression was the same in both cell clones, the expression of the insulin 2 gene was, in agreement with the reduced insulin content of ER-Catalase expressing INS-1E cells, $30 \%$ lower than in control cells (Fig. 6).

\section{Discussion}

$\mathrm{H}_{2} \mathrm{O}_{2}$ generation in the ER through PDI and ERO1, the main enzymes of the oxidative protein folding machinery, is a physiological process in all secretory cells including pancreatic $\beta$ cells (Harding et al. 2003, Gross et al. 2006). Therefore, the question is how cells can cope with these high luminal $\mathrm{H}_{2} \mathrm{O}_{2}$ concentrations and if those huge amounts of $\mathrm{H}_{2} \mathrm{O}_{2}$ may support the folding of nascent

Published by Bioscientifica Ltd 

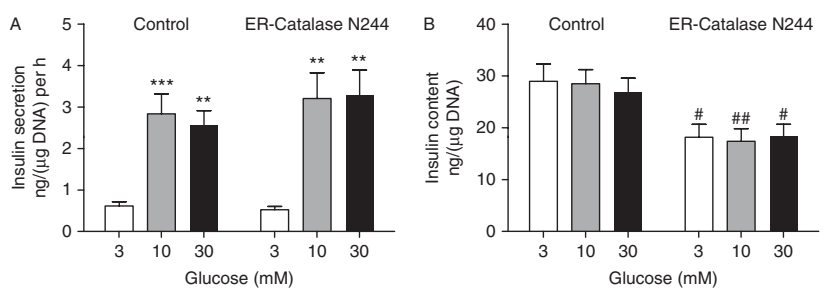

Figure 5

Effects of ER-Catalase N244 expression on glucose-induced insulin secretion, insulin content, and proinsulin content in insulin-secreting INS-1E cells. After $1 \mathrm{~h}$ incubation at $0 \mathrm{mmol} / \mathrm{l}$ glucose INS-1E control and ER-Catalase N244 expressing cells were incubated separately for $2 \mathrm{~h}$ with the indicated glucose concentrations. Thereafter insulin secretion (A) and insulin content (B) were determined by radioimmunoassay. The proinsulin content was quantified by a proinsulin-specific ELISA (C). The insulin

proteins. Both aspects are particularly relevant for insulinsecreting cells to satisfy the high insulin biosynthesis demand, which accounts for roughly 50\% of protein synthesis under physiological conditions (Schuit et al. 1991). States of increased insulin demand, such as insulin resistance in type 2 diabetes, require a further increase of the insulin secretory capacity (DeFronzo et al. 1989). In addition, the expression of $\mathrm{H}_{2} \mathrm{O}_{2}$-degrading enzymes such as catalase and glutathione peroxidase and also of the ER-resident $\mathrm{H}_{2} \mathrm{O}_{2}$-metabolising enzyme $\operatorname{Prdx} 4$ is very low in insulin-secreting cells (Tiedge et al. 1998, Mehmeti et al. 2014). Thus, a possible effect of luminal $\mathrm{H}_{2} \mathrm{O}_{2}$ on oxidative protein folding is likely to be particularly prominent in insulin-secreting cells.

Moreover, there is increasing evidence that ER stress induced by $\beta$ cell toxic cytokines may raise ROS production in the ER (Malhotra \& Kaufman 2007). Although the involvement of nitric oxide and the disturbance of the calcium homeostasis in the ER have been identified as crucial mediators (Oyadomari et al. 2001, Cardozo et al. 2005), the relevance of luminal $\mathrm{H}_{2} \mathrm{O}_{2}$ for these processes is still unsolved.

We therefore investigated the importance of ERspecific $\mathrm{H}_{2} \mathrm{O}_{2}$ degradation in insulin-secreting INS-1E cells for insulin gene expression, insulin content and secretion, as well as for the activation of ER stress cascades through $\beta$ cell toxic cytokines.

In the present study, we could show that insulinsecreting INS-1E tissue culture cells were successfully protected against $\mathrm{H}_{2} \mathrm{O}_{2}$-induced loss of viability through the expression of ER-Catalase N244. The threefold increase of the $\mathrm{EC}_{50}$ value for $\mathrm{H}_{2} \mathrm{O}_{2}$ toxicity documents convincingly the high $\mathrm{H}_{2} \mathrm{O}_{2}$ inactivation capacity of ER-Catalase N244, also when compared with the overexpression of Prdx4 (Mehmeti et al. 2012, Mehmeti et al. 2014) or the
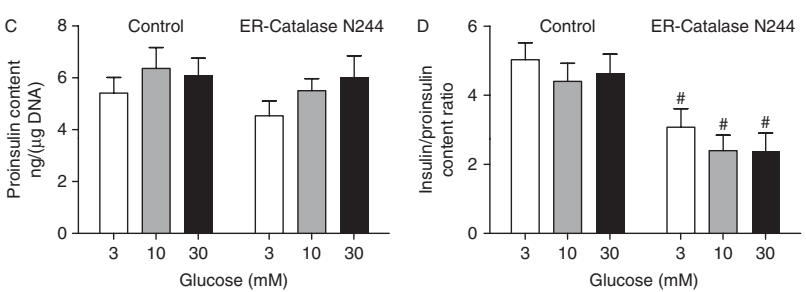

content to proinsulin content ratio was calculated from the presented content data (D). Data are expressed as means \pm s.E.M. of 12 (insulin secretion and content) or nine (proinsulin content) independent experiments. ${ }^{* *} P<0.01$ and $* * * P<0.001$ compared with cells incubated at $3 \mathrm{mmol} / \mathrm{l}$ glucose (ANOVA plus Bonferroni test for multiple comparisons). ${ }^{\#} P<0.05$ and ${ }^{\# \#} P<0.01$ compared with control cells incubated with the same glucose concentration (unpaired two-tailed Student's $t$-test).

targeted expression of a WT catalase cDNA in the ER (Margittai et al. 2012).

This high luminal catalase activity did not change the expression of classical ER stress genes under control conditions and, more importantly, did not counteract the cytokine-induced initiation of the ER stress pathway. Furthermore, the expression of the luminally located protein Grp78/Bip, serving as a central sensor for ER stress due to its function as a molecular chaperone and the activation of the ER stress pathway through its dissociation from IRE1, PERK, and ATF6 (Bertolotti et al.

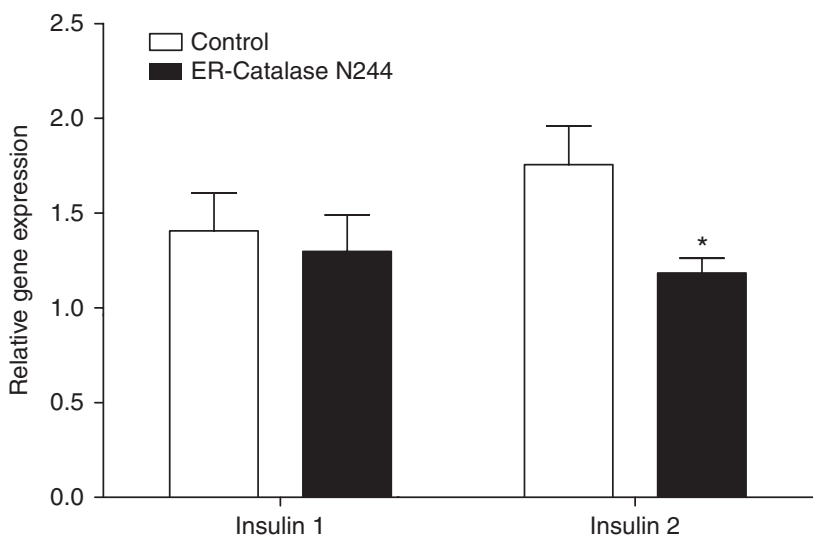

Figure 6

Effects of ER-Catalase N244 expression on insulin 1 and 2 gene expression in insulin-secreting INS-1E cells. INS-1E control (open bars) and ER-Catalase N244 (black bars) expressing cells were incubated for $24 \mathrm{~h}$ under control conditions and thereafter total RNA was isolated and gene expression was analysed by RT-qPCR with insulin 1 and insulin 2 specific primer sets. The expression levels were normalised to the housekeeping genes Tuba4a, Actb, and Ppia. Data are expressed as means \pm s.E.M. of five independent experiments. ${ }^{*} P<0.05$ compared with control cells (unpaired two-tailed Student's $t$-test).

Published by Bioscientifica Ltd. 
2000, Schröder \& Kaufman 2005), was downregulated by the used cytokines independently of the ER-Catalase N244 expression.

These observations indicate either that the luminal $\mathrm{H}_{2} \mathrm{O}_{2}$ concentration is not altered by pro-inflammatory cytokines or that the luminal $\mathrm{H}_{2} \mathrm{O}_{2}$ is not involved in the cytokine-mediated ER stress response. Additionally, ER-Catalase N244 could not antagonise the IL1 $\beta$ - or cytokine mixture-induced cell death, indicating that generation of luminal $\mathrm{H}_{2} \mathrm{O}_{2}$ at variance to mitochondrial $\mathrm{H}_{2} \mathrm{O}_{2}$ is not involved in this process (Gurgul-Convey et al. 2011, Mehmeti et al. 2011).

Although a stimulatory function of $\mathrm{H}_{2} \mathrm{O}_{2}$ on insulin translation and secretion has been considered, the question of a direct influence of $\mathrm{H}_{2} \mathrm{O}_{2}$ on glucose-induced insulin secretion is yet unresolved. As an explanation, the unusually low expression of $\mathrm{H}_{2} \mathrm{O}_{2}$-inactivating enzymes in insulin-secreting cells (Tiedge et al. 1998) has been put forward (Pi et al. 2007, Leloup et al. 2009, Zito et al. 2010). On the other hand, it has been considered that stimulation of insulin biosynthesis in states of increased insulin demand such as insulin resistance in the early stage of type 2 diabetes is accompanied by increased $\mathrm{H}_{2} \mathrm{O}_{2}$ generation in the ER, causing defective insulin secretion, $\beta$ cell dysfunction and ultimately glucose intolerance (Back \& Kaufman 2012). However, an effective removal of $\mathrm{H}_{2} \mathrm{O}_{2}$ in the ER (present study) as well as in mitochondria by a mitochondrially located catalase (Lortz et al. 2013) did not affect glucose-induced insulin secretion. These results do not provide support for a significant role of $\mathrm{H}_{2} \mathrm{O}_{2}$ in glucose-stimulated insulin secretion.

Nevertheless, we could observe a reduction of insulin 2 mRNA expression, insulin content and a decrease of the insulin/proinsulin ratio due to an unchanged proinsulin content. This is in contrast to previous findings after Prdx 4 overexpression, which increased insulin 1 and 2 mRNA expression, insulin content and glucose-induced insulin secretion (Mehmeti et al. 2014). These results indicate that efficient removal of $\mathrm{H}_{2} \mathrm{O}_{2}$ as such by ER-Catalase $\mathrm{N} 244$ does not favour proinsulin protein folding. ER-Catalase N244 expression could not replicate the positive effects of $\operatorname{Prdx} 4$ overexpression on gene expression, biosynthesis and secretion of insulin (Mehmeti et al. 2014).

In conclusion, the present results show that effective elimination of luminal $\mathrm{H}_{2} \mathrm{O}_{2}$ by ER-Catalase N244 left glucose-induced insulin secretion unaffected, even if insulin gene expression and insulin content were reduced. Cellular toxicity induced by pro-inflammatory cytokines and accompanying ER stress were also not abolished.

\section{Declaration of interest}

The authors declare that there is no conflict of interest that could be perceived as prejudicing the impartiality of the research reported.

\section{Funding}

This work has been supported by a grant from the European Union (BetaBAT, Grant Agreement 277713) in the Framework Programme 7.

\section{Author contribution statement}

S Lo and I M contributed to the design, conduct, data analysis and manuscript preparation. S Le contributed to the planning, design, data analysis, and manuscript preparation. All authors approved the final manuscript.

\section{Acknowledgements}

The skilful technical assistance of Maren Böger is gratefully acknowledged.

\section{References}

Asfari M, Janjic D, Meda P, Li G, Halban PA \& Wollheim CB 1992 Establishment of 2-mercaptoethanol-dependent differentiated insulinsecreting cell lines. Endocrinology 130 167-178. (doi:10.1210/endo.130. 1.1370150)

Back SH \& Kaufman RJ 2012 Endoplasmic reticulum stress and type 2 diabetes. Annual Review of Biochemistry 81 767-793. (doi:10.1146/ annurev-biochem-072909-095555)

Bertolotti A, Zhang Y, Hendershot LM, Harding HP \& Ron D 2000 Dynamic interaction of BiP and ER stress transducers in the unfolded-protein response. Nature Cell Biology 2 326-332. (doi:10.1038/ 35014014)

Bhandary B, Marahatta A, Kim HR \& Chae HJ 2012 An involvement of oxidative stress in endoplasmic reticulum stress and its associated diseases. International Journal of Molecular Sciences 14 434-456. (doi:10.3390/ijms14010434)

Bulleid NJ 2012 Disulfide bond formation in the mammalian endoplasmic reticulum. Cold Spring Harbor Perspectives in Biology 4 a013219. (doi:10.1101/cshperspect.a013219)

Cao SS \& Kaufman RJ 2014 Endoplasmic reticulum stress and oxidative stress in cell fate decision and human disease. Antioxidants \& Redox Signaling 21 396-413. (doi:10.1089/ars.2014.5851)

Cardozo AK, Ortis F, Storling J, Feng YM, Rasschaert J, Tonnesen M, Van Eylen F, Mandrup-Poulsen T, Herchuelz A \& Eizirik DL 2005 Cytokines downregulate the sarcoendoplasmic reticulum pump $\mathrm{Ca}^{2+}$ ATPase $2 \mathrm{~b}$ and deplete endoplasmic reticulum $\mathrm{Ca}^{2+}$, leading to induction of endoplasmic reticulum stress in pancreatic $\beta$-cells. Diabetes 54 452-461. (doi:10.2337/diabetes.54.2.452)

DeFronzo RA, Ferrannini E \& Simonson DC 1989 Fasting hyperglycemia in non-insulin-dependent diabetes mellitus: contributions of excessive hepatic glucose production and impaired tissue glucose uptake. Metabolism 38 387-395. (doi:10.1016/0026-0495(89)90129-7)

Gross E, Sevier CS, Heldman N, Vitu E, Bentzur M, Kaiser CA, Thorpe C \& Fass D 2006 Generating disulfides enzymatically: reaction products and electron acceptors of the endoplasmic reticulum thiol oxidase Ero1p. PNAS 103 299-304. (doi:10.1073/pnas.0506448103)

Gurgul-Convey E, Mehmeti I, Lortz S \& Lenzen S 2011 Cytokine toxicity in insulin-producing cells is mediated by nitro-oxidative stress-induced hydroxyl radical formation in mitochondria. Journal of Molecular Medicine 89 785-798. (doi:10.1007/s00109-011-0747-1) http://jme.endocrinology-journals.org DOI: 10.1530/JME-15-0132
() 2015 Society for Endocrinology Printed in Great Britain 
Harding HP \& Ron D 2002 Endoplasmic reticulum stress and the development of diabetes: a review. Diabetes 51 (Suppl 3) S455-S461. (doi:10.2337/diabetes.51.2007.S455)

Harding HP, Zhang Y, Zeng H, Novoa I, Lu PD, Calfon M, Sadri N, Yun C, Popko B, Paules R et al. 2003 An integrated stress response regulates amino acid metabolism and resistance to oxidative stress. Molecular Cell 11 619-633. (doi:10.1016/S1097-2765(03)00105-9)

Leloup C, Tourrel-Cuzin C, Magnan C, Karaca M, Castel J, Carneiro L, Colombani AL, Ktorza A, Casteilla L \& Penicaud L 2009 Mitochondrial reactive oxygen species are obligatory signals for glucose-induced insulin secretion. Diabetes 58 673-681. (doi:10.2337/db07-1056)

Lortz S, Gurgul-Convey E, Naujok O \& Lenzen S 2013 Overexpression of the antioxidant enzyme catalase does not interfere with the glucose responsiveness of insulin-secreting INS-1E cells and rat islets. Diabetologia 56 774-782. (doi:10.1007/s00125-012-2823-7)

Lortz S, Lenzen S \& Mehmeti I 2015 N-glycosylation-negative catalase: a useful tool for exploring the role of hydrogen peroxide in the endoplasmic reticulum. Free Radical Biology \& Medicine 80 77-83. (doi:10.1016/j.freeradbiomed.2014.11.024)

Malhotra JD \& Kaufman RJ 2007 Endoplasmic reticulum stress and oxidative stress: a vicious cycle or a double-edged sword? Antioxidants \& Redox Signaling 9 2277-2293. (doi:10.1089/ars.2007.1782)

Malhotra JD, Miao H, Zhang K, Wolfson A, Pennathur S, Pipe SW \& Kaufman RJ 2008 Antioxidants reduce endoplasmic reticulum stress and improve protein secretion. PNAS 105 18525-18530. (doi:10.1073/ pnas.0809677105)

Margittai E, Low P, Stiller I, Greco A, Garcia-Manteiga JM, Pengo N, Benedetti A, Sitia R \& Banhegyi G 2012 Production of $\mathrm{H}(2) \mathrm{O}(2)$ in the endoplasmic reticulum promotes in vivo disulfide bond formation. Antioxidants \& Redox Signaling 16 1088-1099. (doi:10.1089/ars.2011.4221)

Mehmeti I, Gurgul-Convey E, Lenzen S \& Lortz S 2011 Induction of the intrinsic apoptosis pathway in insulin-secreting cells is dependent on oxidative damage of mitochondria but independent of caspase-12 activation. Biochimica et Biophysica Acta 1813 1827-1835. (doi:10.1016/ j.bbamcr.2011.06.022)

Mehmeti I, Lortz S \& Lenzen S 2012 The $\mathrm{H}(2) \mathrm{O}(2)$-sensitive HyPer protein targeted to the endoplasmic reticulum as a mirror of the oxidizing thiol-disulfide milieu. Free Radical Biology \& Medicine 53 1451-1458. (doi:10.1016/j.freeradbiomed.2012.08.010)

Mehmeti I, Lortz S, Elsner M \& Lenzen S 2014 Peroxiredoxin 4 improves insulin biosynthesis and glucose-induced insulin secretion in insulinsecreting INS-1E cells. Journal of Biological Chemistry 289 26904-26913. (doi:10.1074/jbc.M114.568329)
Mosmann T 1983 Rapid colorimetric assay for cellular growth and survival: application to proliferation and cytotoxicity assays. Journal of Immunological Methods 65 55-63. (doi:10.1016/0022-1759(83)90303-4)

Oyadomari S, Takeda K, Takiguchi M, Gotoh T, Matsumoto M, Wada I, Akira S, Araki E \& Mori M 2001 Nitric oxide-induced apoptosis in pancreatic $\beta$ cells is mediated by the endoplasmic reticulum stress pathway. PNAS 98 10845-10850. (doi:10.1073/pnas.191207498)

Pi J, Bai Y, Zhang Q, Wong V, Floering LM, Daniel K, Reece JM, Deeney JT, Andersen ME, Corkey BE et al. 2007 Reactive oxygen species as a signal in glucose-stimulated insulin secretion. Diabetes 56 1783-1791. (doi:10.2337/db06-1601)

Ramming T \& Appenzeller-Herzog C 2012 The physiological functions of mammalian endoplasmic oxidoreductin 1: on disulfides and more. Antioxidants \& Redox Signaling 16 1109-1118. (doi:10.1089/ars.2011. 4475)

Ramming T \& Appenzeller-Herzog C 2013 Destroy and exploit: catalyzed removal of hydroperoxides from the endoplasmic reticulum. International Journal of Cell Biology 2013 180906. (doi:10.1155/2013/ 180906)

Scheuner D \& Kaufman RJ 2008 The unfolded protein response: a pathway that links insulin demand with $\beta$-cell failure and diabetes. Endocrine Reviews 29 317-333. (doi:10.1210/er.2007-0039)

Schröder M \& Kaufman RJ 2005 The mammalian unfolded protein response. Annual Review of Biochemistry 74 739-789. (doi:10.1146/ annurev.biochem.73.011303.074134)

Schuit FC, Kiekens R \& Pipeleers DG 1991 Measuring the balance between insulin synthesis and insulin release. Biochemical and Biophysical Research Communications 178 1182-1187. (doi:10.1016/0006291X(91)91017-7)

Tiedge M, Lortz S, Munday R \& Lenzen S 1998 Complementary action of antioxidant enzymes in the protection of bioengineered insulinproducing RINm5F cells against the toxicity of reactive oxygen species. Diabetes 47 1578-1585. (doi:10.2337/diabetes.47.10.1578)

Tu BP \& Weissman JS 2004 Oxidative protein folding in eukaryotes: mechanisms and consequences. Journal of Cell Biology 164 341-346. (doi:10.1083/jcb.200311055)

Zito E, Melo EP, Yang Y, Wahlander A, Neubert TA \& Ron D 2010 Oxidative protein folding by an endoplasmic reticulum-localized peroxiredoxin. Molecular Cell 40 787-797. (doi:10.1016/j.molcel.2010. 11.010)

Zufferey R, Dull T, Mandel RJ, Bukovsky A, Quiroz D, Naldini L \& Trono D 1998 Self-inactivating lentivirus vector for safe and efficient in vivo gene delivery. Journal of Virology 72 9873-9880.

Received in final form 14 June 2015

Accepted 15 June 2015

Accepted Preprint published online 24 June 2015 http://jme.endocrinology-journals.org

DOI: $10.1530 / \mathrm{JME}-15-0132$
(C) 2015 Society for Endocrinology Printed in Great Britain
Published by Bioscientifica Ltd. 